\title{
Program Pemberdayaan Sebagai Aktivitas Corporate Social Responsibility Studi Kasus Pemberdayaan Penderes di Pangandaran
}

\author{
Rahmad Efendi \\ Komunitas Antronesia \\ rahmad.efendi@hotmail.co.id
}

\begin{abstract}
This article examines the phenomenon of the implementation of community empowerment program as the Corporate Social Responsibility (CSR) activity, which is used as a strategy to control the supply chain of raw materials. This paper prepared using qualitative research methods with field study at Pangandaran District, West Java. The Pangandaran Tappers Community Empowerment Program has been run by PT Ultrava since 2012 until 2014. The program is aimed to manage the brown sugar supply chain problems in Pangandaran that caused by the tappers. For that purpose, Ultrava running the govermentality agenda against all of the brown sugar supply chain actors in Pangandaran. The govermentality agenda use the biopolitic and subjectivity process, to change the tappers became the obedient subject to the will of Ultrava.
\end{abstract}

Keywords : CSR, Empowerment, Govermentality

\begin{abstract}
Abstrak
Artikel ini mengkaji fenomena pelaksanaan program pemberdayaan masyarakat sebagai Corporate Social Responsibility (CSR), yang digunakan sebagai strategi untuk mengendalikan rantai pasokan bahan baku. Artikel ini disusun dengan menggunakan metode penelitian kualitatif dengan studi lapangan di Kabupaten Pangandaran, Jawa Barat. Program Pemberdayaan Penderes Pangandaran telah dijalankan oleh PT Ultrava sejak 2012 hingga 2014. Program ini bertujuan untuk mengelola masalah rantai pasokan gula di Pangandaran yang disebabkan oleh penderes. Untuk itu, Ultrava menjalankan agenda govermentality terhadap semua pelaku rantai pasokan gula di Pangandaran. Agenda govermentality tersebut menggunakan proses biopolitic dan subjectivity, untuk mengubah penderes menjadi subyek yang patuh kepada kehendak Ultrava.
\end{abstract}

\section{Pendahuluan}

Corporate Social Responsibility (CSR) pada awalnya muncul sebagai tuntutan terhadap perusahaan untuk bertanggungjawab atas aktivitas mereka yang menimbulkan dampak negatif terhadap masyarakat dan lingkungan. Namun dalam perkembangan berikutnya, alihalih dilihat sebagai beban moral, korporasi malah menjadikan CSR sebagai suatu strategi bisnis baru. Menurut Sukada dkk (2007), pergeseran itu berawal dari munculnya gagasan bussines sustainability yang melihat keberlangsungan bisnis tak hanya bergantung pada efisiensi pemanfaatan sumber daya dalam mengakumulasi laba, namun juga bergantung pada upaya meningkatkan kualitas sosial, ekonomi, budaya masyarakat, dan 
keberlanjutan lingkungan, untuk menghindarkan perusahaan dari berbagai macam potensi kerugian. Seperti yang dipetakan oleh Blowfield \& Frynas (2009:6), saat ini CSR dimaknai sebagai suatu konsep besar yang memayungi; (a) tanggung jawab perusahaan terhadap dampak operasionalnya bagi masyarakat dan lingkungan alam; (b) perilaku bertanggung jawab dari perusahaan dalam berbisnis dengan shareholder (pemilik saham) dan stakeholder (karyawan, pemasok, konsumen, dll); dan (c) kebutuhan bisnis untuk mengelola hubungan perusahaan dengan masyarakat luas, apakah untuk menjaga kepentingan bisnis maupun untuk kebaikan bagi masyarakat.

Perhatian terhadap pengembangan kapasitas dan kesejahteraan para stakeholders, yakni pekerja, pemasok, komunitas di lingkungan perusahaan, dan konsumen, telah menjadi prioritas penting dalam CSR. Upaya-upaya peningkatan kapasitas yang dilakukan perusahaan mulai dari kegiatan charity, pelatihan hingga pemberdayaan komunitas (community empowerment). Radyati (2008:31-32) melihat bahwa tenaga kerja dan pemasok merupakan stakeholder prioritas untuk diberdayakan. Sebab, rantai pasok bisa memberikan risiko krusial bagi perusahaan, yakni risiko operasional, finansial, dan reputasi. Risiko operasional dari rantai pasok terkait dengan kendala-kendala dalam proses distribusi barang dan jasa. Masalah dalam operasional berasal dari sumber bahan baku, para produsen bahan baku, dan kondisikondisi yang mempengaruhinya. Sementara itu risiko reputasi terkait dengan rusaknya nama baik perusahaan akibat masalah operasional. Sebab itu, pelaksanaan pemberdayaan terhadap pemasok menjadi suatu keunggulan kompetitif dalam CSR. Dengan memberdayakan para pemasok,

\footnotetext{
${ }^{1}$ GRI adalah pedoman laporan sustainability report bagi perusahaan. GRI menggunakan tiga pilar sustainability, yang terkenal dengan triple bottom line (profit, people,

Volume 1 (2) Desember 2016 eISSN 2528-1569 pISSN 2528-2115
}

perusahaan bisa meminimalisir resiko-resiko tersebut.

Setidaknya dapat ditemukan empat manfaat program pemberdayaan terhadap pemasok. Pertama, dengan melaksanakan program pemberdayaan, perusahaan memiliki kesempatan secara tidak langsung mendidik dan mengembangkan kapasitas para pemasok untuk meningkatkan kualitas dan kuantitas produksi. Upaya ini diharapkan menghasilkan komunitas pemasok yang mampu menjadi mitra jangka panjang bagi perusahaan (Radyati 2008:48). Kedua, peningkatan produktivitas pemasok diharapkan menghasilkan peningkatan kesejahteraan hidup para pemasok. Sehingga bisa meningkatkan kepercayaan dan loyalitas pemasok terhadap perusahaan (Nursahid 2008:100). Ketiga, program pemberdayaan bermanfaat untuk mengajak pemasok menjalankan aktivitas produksi yang menjaga kelestarian alam. Sehingga bisa bermanfaat untuk menjaga kelangsungan sumber bahan baku produksi (Leimona \& Fauzi 2008:8-9). Keempat, aspek pemberdayaan bernilai tinggi dalam penilaian Global Reporting Initiative (GRI). ${ }^{1}$ Keberhasilan program pemberdayaan membuat peringkat sustainablity perusahaan semakin baik, dan hal itu memberi arti pada reputasi (Porter dan Kramer 2001 dalam Radyati 2008:21).

Pemanfaatan CSR dalam pengelolaan rantai pasok pada akhirnya menunjukkan jargon "bahwa dalam kapitalisme, tidak ada makan siang gratis" juga berlaku dalam CSR. Pemberdayaan pada pemasok bukanlah semata-mata niat baik tanpa motif. Sebaliknya, terdapat beragam keuntungan yang diharapkan dari pelaksanaan pemberdayaan itu untuk meningkatkan profit perusahaan. Menurut Dolan \& Rajak dalam

\& planet), sebagai patokan dalam pengelompokan indikator kinerja perusahaan (Radyati 2008:40-41). 
buku The Anthropology of Corporate Social Responsibility (2016), kondisi seperti itulah yang membuat CSR menjadi salah satu subjek yang semakin popular dalam literatur antropologi dalam satu dekade terakhir. Dolan \& Rajak mengkaji CSR dengan penekanan terkait persoalan moral ekonomi dunia industri. CSR dilihat sebagai relasi sosial antara perusahaan dengan para konsumen, produsen, dan stakeholder yang lebih luas, yang menjadi domain baru untuk menjalankan kekuasaan perusahaan terhadap stakeholder tersebut. CSR dapat ditelaah sebagai suatu hadiah (gift), kontrak sosial (social contract) dan resiprositas (reciprocity) antara perusahaan sebagai dengan stakeholder-nya. Di sisi lain CSR juga bisa dilihat sebagai redistribusi (redistribution) perusahaan sebagai patron terhadap stakeholder-nya. Semua itu dilakukan dalam rangka menghaluskan sekaligus mempertegas dominasi ekonomi perusahaan terhadap para stakeholder.

Dolan \& Rajak juga menjelaskan bahwa landasan moral ekonomi telah membuat pelaksanaan CSR semakin dekat dalam kegiatan pembangunan. Keterkaitan paling nyata terlihat dari maraknya pelaksanaan program pemberdayaan komunitas sebagai CSR. Salah satunya dalam bentuk pelaksanaan pemberdayaan sebagai CSR terhadap pemasok. Dalam tren seperti itu, CSR menjadi penghalus sekaligus penguat dominasi ekonomi perusahaan terhadap stakeholder. Hal ini mengingatkan tentang agenda kepengaturan yang melekat dalam setiap program pembangunan. Seperti yang diungkapkan oleh Tania Murray Li (2012), kepengaturan merupakan upaya mengarahkan perilaku manusia dengan serangkaian cara yang telah dikalkulasi sedemikian rupa (Li 2012:9). Kepengaturan bekerja dengan mengarahkan minat dan membentuk kebiasaan, cita-cita dan kepercayaan (David Scott 1995:202 dalam Li 2012:10)." Dalam kaitannya dengan kepentingan kapitalisme, kepengaturan bertujuan untuk mengarahkan masyarakat pada jalan yang yang melanggengkan dominasi para penguasa kapitalis (Li 2012:41).

Seperti yang diterangkan Dede Mulyanto (2012), kepentingan kapitalis dalam kepengaturan merupakan ciri antropologis dari kapitalisme, yakni kesadaran akan keberlanjutan usaha penghisapan nilai lebih dengan cara-cara rasional dan berkelanjutan (Mulyanto 2012:105). Pendisiplinan arus sirkulasi kapital harus diiringi oleh pendisiplinan arus konsumsi tenaga-kerja manusianya, karena reproduksi kapital tidaklah mungkin dilepaskan dari reproduksi manusia sebagai sumber daya produksi (Foucault 1978:216-28, dalam Mulyanto 2012:188). Pendidikan adalah upaya yang dilakukan untuk pendisiplinan itu. Sebagaimana dulu politik etis kolonial yang mendidik bumiputra untuk bisa mengisi posisi administratif sehingga mengurangi biaya mendatangkan pekerja dari Eropa (Mulyanto 2012:165). Sehingga, kepengaturan merupakan alat menghasilkan tubuh yang patuh yang berguna dalam rangka pengelolaan subyek buruh di bawah sistem kapitalisme (Sherman 2015a).

\section{Objek Kajian dan Metode Penelitian}

Tulisan ini mengkaji kasus pemanfaatan program pemberdayaan sebagai CSR terhadap pemasok bahan baku. Penulis terlibat langsung sebagai fasilitator dalam program ini selama satu setengah tahun, dari November 2011 s/d Maret 2013. Selama terlibat dalam program ini, penulis menyadari bagaimana program tersebut disusun dan dikembangkan untuk kepentingan pengelolaan rantai pasok alih-alih memberikan pemberdayaan yang membebaskan bagi para penderes.

Kasus tersebut adalah Program Pemberdayaan Penderes Gula Kelapa sebagai aktivitas CSR PT Ultrava di Pangandaran. Program 
pemberdayaan ini ditujukan pada pemasok bahan baku Kecap Bravo, yakni para penderes di wilayah Kab. Pangandaran yang berasal dari rantai pasok PT Sentosa. Program ini dikelola oleh Yayasan Bakti Ultrava (YBU) dengan bantuan dari Gabungan Pengusaha Gula Kelapa (GPGK), Yayasan Citra Semesta (YCS), Yayasan Fasilitasi Inklusi (YFI) dan Institusi Pemerintahan setempat.

Penelitian ini dilakukan di seluruh area pelaksanaan program, dengan informan yang berasal dari para pihak terlibat, termasuk 10 komuniti penderes jaringan PT Sentosa yang tersebar dalam empat kecamatan yakni, Pangandaran, Sidamulih, Kalipucang dan Cimerak.

Metode yang digunakan dalam penelitian ini adalah metode kualitatif dengan melakukan pengamatan terlibat dan wawancara mendalam. Unit analisis penelitian ini adalah program pemberdayaan penderes yang menjadi CSR Ultrava terhadap rantai pasok PT Sentosa. Keterlibatan penulis dalam program memberi peluang yang besar bagi penulis untuk mengamati proses yang terjadi. Namun pada saat yang sama, penulis harus berjuang keras untuk memilah setiap informasi secara objektif agar tidak terjebak dengan bias penulis sebagai bagian dari program.

Untuk menjaga kerahasiaan para informan, semua identitas pihak yang menjadi objek kajian dan sumber informasi telah disamarkan. Nama-nama perusahaan, merek, program, dan lembaga yang dicantumkan dalam tulisan ini hanya sekedar samaran dari identitas asli.

${ }^{2}$ Gula kelapa adalah salah satu bahan pemanis pangan. Gula kelapa diolah dari nira kelapa (Cocos Nucifera Lin), yaitu cairan bening dari dalam mayang kelapa yang ditoreh. Nira hasil sadapan kemudian dimasak dalam wajan besi dengan suhu di atas 100 derajat Celcius hingga mengental seperti adonan kenyal berwarna cokelat kemerahan. Adonan tersebut

\section{Kontradiksi Internal Rantai Pasok Gula Kelapa Pangandaran Untuk Kecap Bravo}

Aktivitas produksi gula kelapa ${ }^{2}$ di wilayah Pangandaran bermula sekitar tahun 1950-an. Menurut pihak Gabungan Pengusaha Gula Kelapa (GPGK), pada tahun 1950-an, aktivitas produksi gula kelapa bukanlah mata pencaharian bagi penduduk, melainkan sekedar kegiatan selingan untuk memenuhi kebutuhan gula rumah tangga. Pada awal 1960-an, gula kelapa mulai menjadi komoditi yang diperdagangkan. Kemudian sejak pabrik kecap mulai membeli gula kelapa di Pangandaran pada tahun 1980-an, komoditas itu menjadi semakin popular dan menjadi sektor ekonomi penting bagi masyarakat dan pemerintah.

Pada tahap ini, produksi gula kelapa telah masuk dalam kategori industri rumahan dengan ciri umum sebagai berikut ; (1) industri ekstraktif (memanfaatkan bahan baku yang diambil langsung dari alam), (2) industri hulu (menghasilkan produk setengah jadi sebagai bahan baku untuk industri lain), (3) industri tradisional (teknologi sederhana, ada di wilayah pedesaan dan akses pasar terbatas), (4) industri padat karya (lebih bergantung pada tenaga kerja dibanding modal), dan (5) industri kecil skala rumah tangga (hanya melibatkan tenaga kerja antara 1-4 orang saja). ${ }^{3}$

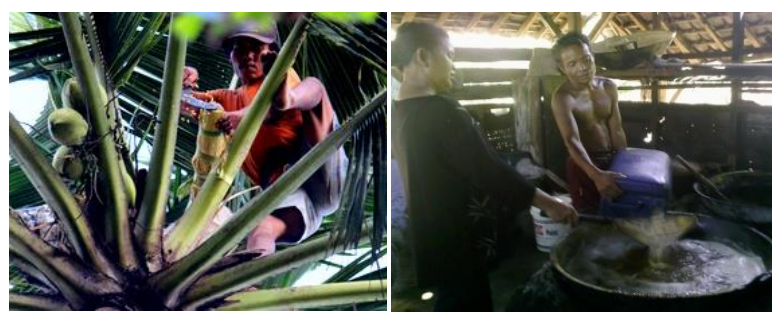

kemudian dituang ke dalam cetakan bambu, kayu atau plastik, dan disimpan hingga dingin dan keras. Adonan yang sudah mengeras itulah yang dikenal sebagai gula kelapa.

3 Pengklasifikasian tersebut menggunakan kategori dalam Surat Keputusan Menteri Perindustrian No. 19/M/I/1986. 
Proses menderes mayang kelapa

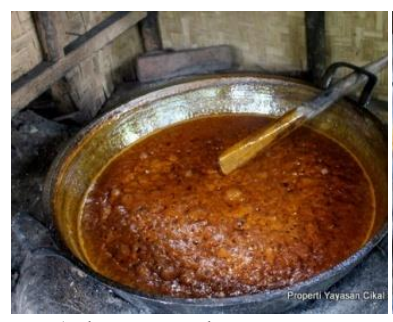

Adonan gula yang sudah matang
Penderes dan istrinya menyaring nira sebelum masuk katel

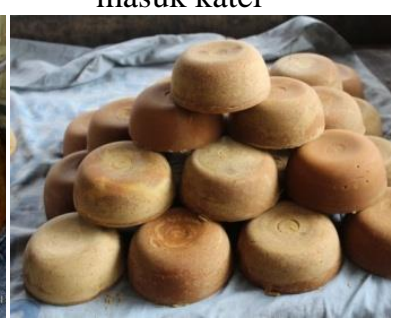

Gula batok kualitas standar untuk pabrik kecap

Dalam rantai pasok gula kelapa untuk pabrik kecap, setidaknya ada tiga mata rantai utama, yakni, para penderes selaku produsen, para pengepul dan bandar gula sebagai perantara, dan pabrik kecap sebagai pembeli. Penderes merupakan istilah yang berlaku umum di Pangandaran untuk menyebut orang yang melakukan aktivitas produksi gula kelapa, mulai dari menderes/menyadap nira kelapa, hingga memasak dan mencetak gula. Sementara pengepul dan Bandar adalah pihak yang membeli gula dari penderes dan menjualnya ke pembeli, misalnya pabrik kecap.

Setidaknya ada empat pabrik kecap skala nasional yang membeli gula kelapa ke Pangandaran. Namun pabrik kecap Bravo milik Ultrava adalah pembeli utama gula kelapa Pangandaran. Pada tahun 2011-2012, jumlah pasokan yang diterima pabrik Kecap Bravo dari wilayah Pangandaran mencapai 600 ton/minggu, atau sekitar $75 \%$ dari total produksi gula kelapa di Pangandaran. Pembelian sebesar itu menempatkan pabrik Kecap Bravo sebagai pembeli utama gula kelapa Pangandaran. Bandar gula yang menjadi pemasok utama Kecap Bravo adalah PT Sentosa. Dari pembukuan PT Sentosa

4 Dalam sistem Borsom produsen gula (kelapa) meminjam uang dan kemudian terikat hutang dengan patron mereka. Para produsen itu kemudian diharuskan menjual gula pada patron mereka (Secretariat AsiaDHRRA 1998:65). Pada prinsipya pengepul

sejak bulan Januari 2010 s/d bulan Maret 2011, total omzet gula kelapa adalah sebesar 18.621,33 Ton, atau sekitar 332.5 ton/minggu (PT Sentosa 2011). Dari jumlah itu PT Sentosa menguasai setidaknya $41.5 \%$ dari total suplai gula kelapa untuk Kecap Bravo.

PT Sentosa biasanya mendapatkan gula kelapa dari pengepul, namun ada juga langsung dari penderes. Pengepul PT Sentosa merupakan perpanjangan tangan PT Sentosa dalam mendapatkan setoran gula kelapa secara langsung dari penderes. Pengepul biasanya mampu menampung setoran penderes dari cakupan satu dusun hingga satu desa. Sebagai hulu dari industri gula kelapa, adalah para penderes yang menjadi produsen gula kelapa. Penderes yang menjadi pemasok untuk pabrik kecap Bravo ada yang termasuk jaringan PT Sentosa, dan ada juga yang termasuk jaringan bandar lain. Pada tahun 2015, dari 139 ranting, PT Sentosa memiliki 5.500 penderes. Secara umum, penderes yang berada dalam jaringan PT Sentosa semuanya adalah laki-laki, berusia antara 15-63 tahun, dan mayoritas berpendidikan setingkat Sekolah Dasar.

Dalam sistem internal PT Sentosa (yang juga terjadi di bandar lainnya), ikatan bisnis dengan pengepul dan penderes umumnya menggunakan asas ikatan hutang-piutang. Sistem ini cukup umum dalam usaha gula kelapa di pulau Jawa. PT Sentosa menyebut relasi itu sebagai sistem kemitraan. Sementara di Sukabumi sistem ini dikenal dengan istilah Borsom. ${ }^{4}$ Dalam sistem ini ini, awalnya PT Sentosa memberi pinjaman uang pada pengepul yang digunakan untuk memancing penderes. Pinjaman ini biasanya berupa pinjaman modal awal untuk membangun unit produksi gula kelapa, yakni untuk membiayai keperluan produksi seperti dapur, tungku,

memberikan hutang sebagai pengikat agar pengrajin atau pengepul yang diberi hutang tersebut memberikan pasokan gula secara rutin (Widyaningrum dkk 2003:56). 
katel, alat deres, bahan bakar, dan biaya sewa pohon kelapa. Bagi para penderes yang kemudian tertarik dan akhirnya meminjam uang kepada pengepul, maka secara otomatis akan tercatat menjadi anggota pengepul tersebut. Ikatan hutang itu sulit dilepas oleh penderes, meskipun sudah melunasi, mereka biasanya berhutang kembali, dan lebih sering untuk memenuhi kebutuhan konsumsi rumah tangganya.

Pelestarian sistem hutang ini merupakan sebuah hubungan yang eksploitatif. Penderes harus menerima bahwa sepanjang hutang masih ada, mereka harus tetap menyetor pada pengepul yang dihutangi. Sementara, pengepul menetapkan bahwa adanya hutang menjadi legitimasi untuk menurunkan harga beli gula kelapa penderes di bawah harga pasar, atau mereka menetapkan bunga yang mahal. Pada beberapa kasus, berdasarkan ikatan hutang, pengepul bahkan bisa menjadikan penderes sebagai pekerja baginya. Di satu sisi, pengepul mendapatkan gula dengan harga murah, di sisi lain mendapatkan para penderes yang bekerja untuknya tanpa digaji. Relasi antara penderes dan pengepul adalah relasi produksi yang paling dasar dalam usaha gula kelapa, dan bersifat eksploitatif.

Akibat eksploitasi yang terjadi di dalam rantai pasok gula kelapa, penderes pada akhirnya menjadi korban dalam proses penghisapan itu. Sebab itulah nasib para penderes tak sejalan dengan manisnya bisnis gula kelapa yang dinikmati oleh para pengusaha dan pemerintah. Pada akhirnya, profesi penderes itu sendiri bukanlah sesuatu yang diharapkan bagi masyarakat di Pangandaran. Menjadi penderes adalah sebuah kecelakaan, sebuah pilihan terakhir bagi mereka yang tidak punya harapan lagi untuk mendapatkan sumber mata pencaharian yang lain. Setidaknya ada 10 bentuk kesulitan hidup sebagai penderes yang menjadi alasan mengapa pekerjaan menderes bukanlah profesi yang diinginkan oleh penduduk Pangandaran. Yakni : 1) dipandang rendah oleh masyarakat, 2) menanggung risiko kerja yang tinggi, 3) berhadapan dengan pengaruh alam yang tidak pasti, 4) tuntutan waktu kerja yang lama, 5) mengeluarkan biaya produksi yang cukup besar, 6) menerima harga gula yang tidak stabil, 7) menerima pendapatan yang juga tidak stabil, 8) terikat hutang pada pengepul, 9) menerima tekanan dari Ultrava lewat PT Sentosa dan rantingrantingnya untuk menjalankan standar-standar operasional tertentu, dan 10) tidak memiliki jaminan sosial jika mengalami kecelakaan kerja.

Berbagai kesulitan hidup itu menjadi faktor pemicu yang membuat penderes kecewa atas apa yang mereka dapatkan dari kemitraan dengan pengepul dan PT Sentosa. Di tengah kehidupan mereka yang sulit, kemitraan dengan pihak PT Sentosa tidak memberi perbaikan yang berarti bagi mereka, sebaliknya malah memberikan beban tambahan. Dalam menghadapi berbagai tekanan dalam hubungan kemitraan itu, muncul resistensi penderes. Bentuk resistensi paling umum dari para penderes adalah dengan mengabaikan berbagai standar kualitas gula yang diminta. Bentuk berikutnya adalah dengan 'nyeleweng" ke pengepul yang membeli gula lebih mahal, yang bisa jadi di luar jaringan PT Sentosa. Resistensi lainnya adalah sabotase bahan baku dan kualitas gula. Dalam aksi ini, "oknum pelaku" biasanya memproduksi "gula kelapa oplosan," dengan mencampurkan bahan-bahan lain seperti ubi ke dalam adonan gula.

Pabrik Kecap Bravo pernah menolak puluhan ton kiriman gula dari PT Sentosa, hanya karena menemukan beberapa kilogram gula oplosan dalam kiriman tersebut. Tentu saja kerugian yang ditanggung PT Sentosa akibat kejadian itu cukup besar. PT Sentosa merespon gula oplosan ini dengan pengontrolan sumber gula dan penurunan harga beli. Pihak PT Sentosa mulai dengan menandai beberapa wilayah yang terindikasi 
sering menjadi pemasok gula oplosan. Adapun pelakunya akan mendapat ganjaran hukuman sosial (/di-blacklist oleh ranting/ PT Sentosa) dan hukum pidana. Setelah itu, PT Sentosa akan menurunkan harga beli gula kelapa pada pengepul. Penurunan harga beli bisa mencapai Rp 300,-/kg. Pihak PT Sentosa beralasan bahwa penurunan harga itu untuk menutupi kerugian dari biaya transportasi gula kelapa yang ditolak pabrik Kecap Bravo.

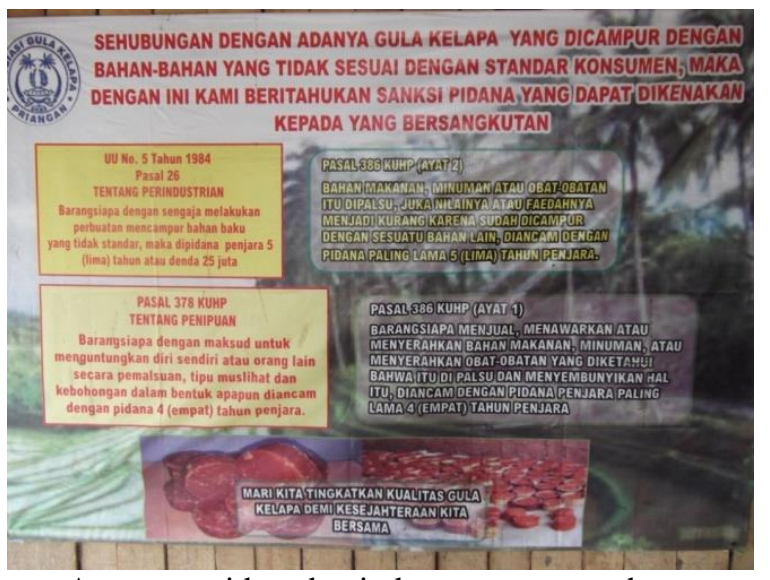

Ancaman pidana bagi oknum yang membuat gula kelapa oplosan

Dari perkembangan industri gula kelapa di Pangandaran, terlihat bahwa hubungan produksi kapitalistik yang dibawa pabrik kecap, telah merubah wajah usaha gula kelapa di Pangandaran. Produksi gula kelapa yang awalnya pekerjaan tidak terikat dan sekedar untuk kebutuhan subsisten bagi penderes, telah menjadi mesin penghisapan berlapis akibat kepentingan industri pabrik kecap, terutama Ultrava. Semuanya menjadi terpusat hanya untuk bekerja dan menjual pada Ultrava. Fenomena ini merupakan contoh dari penjelasan Mulyanto (2012), tentang penetrasi kapitalisme yang akan selalu menghisap berbagai moda produksi yang lain untuk berjalan sesuai dengan aturan kapitalisme. Proses penghisapan itu tidak menghilangkan, namun merubah wajah dan perilaku dari moda

Volume 1 (2) Desember 2016 eISSN 2528-1569 pISSN 2528-2115 produksi lama menjadi pelayan dalam proses akumulasi kapital.

Ultrava menjadi pusat gravitasi dalam usaha gula kelapa di Pangandaran. Keputusan Ultrava bisa mempengaruhi kondisi gula kelapa di Pangandaran. Kehadirannya menciptakan ketergantungan bagi banyak pihak, baik penderes, pengepul maupun bandar. Pada titik inilah bekerja apa yang dijelaskan Marx (dalam Sherman 2015a), suatu kekuasaan dominasi ekonomi kelas kapitalis, yakni kekuasaan yang dimiliki sebagai konsekuensi penguasaan terhadap kapital. Dari kekuasaan jenis inilah bersumbernya legitimasi Ultrava menjalankan berbagai agenda kepengaturan terhadap rantai pasok gula kelapa di Pangandaran.

Akan tetapi, Ultrava dan PT Sentosa ditantang oleh kasus penyelewengan dan gula oplosan yang terjadi akibat perlawanan penderes. Meskipun sudah dilakukan tindakan tegas, namun gula oplosan tetap menjadi ancaman laten dalam rantai pasok gula kelapa untuk Kecap Bravo. Pihak Ultrava melihat hal itu sebagai persoalan manajerial, dan kemudian mengambil inisiatif untuk turun langsung menghadapi persoalan tersebut. Salah satu langkah yang ditempuh adalah menerapkan USAM dengan memanfaatkan program pemberdayaan.

\section{Program Pemberdayaan Penderes Sebagai Implementasi CSR PT Ultrava}

Sejak tahun 2010, Ultrava merilis kebijakan Corporate Social Responsibility (CSR) yang dikenal dengan nama Ultrava Sustainable Plan (USP). USP memiliki tiga tujuan besar untuk dicapai di tahun 2020, salah satunya adalah membuat $100 \%$ sumber bahan baku pertanian berkelanjutan dan meningkatkan penghidupan dari orang-orang sepanjang rantai nilai. Terkait dengan tujuan tersebut, Ultrava meluncurkan Ultrava Sustainable Agriculture Management (USAM). USAM 
meminta para pemasok bahan baku pertanian mengadopsi praktek keberlanjutan di lahan mereka. Pada tahun 2011 Ultrava menugaskan Yayasan Bakti Ultrava (YBU) untuk menerapkan USAM di rantai pasok gula kelapa Pangandaran.

Kecap Bravo merupakan salah satu produk Ultrava yang menjadi sasaran dari penerapan USAM. Sumber bahan baku Kecap Bravo bergantung penuh dari sumber daya pertanian, yakni kedelai hitam dan gula kelapa. Sebab itu, Kecap Bravo mendapat prioritas dalam pelaksanaan USAM. Dalam roadmap penerapan USAM, pada tahun 2012-2015 dilakukan Program Pemberdayaan terhadap pemasok bahan baku Kecap Bravo, yakni petani kedelai hitam di Yogyakarta, Jawa Tengah dan Jawa Timur ${ }^{5}$ dan penderes gula kelapa di Pangandaran, Jawa Barat. ${ }^{6}$ Sesuai roadmap, pada tahun 2012 YBU mulai memperkenalkan standar USAM pada penderes di Pangandaran. Kemudian pada tahun 2013 mulai melakukan uji coba penerapan. Selanjutnya pada tahun 2014 melakukan verifikasi tingkat keberhasilan penerapan. Di tahun 2015, penerapan USAM dilakukan secara merata di seluruh rantai pasok gula kelapa di Pangandaran.

USAM merupakan aktivitas CSR Ultrava yang menggunakan manajemen rantai pasok dan pemberdayaan secara bersamaan. Untuk itu, YBU mengembangkan program Pemberdayaan Penderes Pangandaran tahun 2012-2015 dalam enam bidang berikut, yaitu: (1) Pengembangan kelompok (community organizing). (2) Pembibitan dan penanaman bibit kelapa (replanting). (3) Pembuatan pupuk dan pemeliharaan pohon sadapan

\footnotetext{
${ }^{5}$ Program manajemen rantai pasok juga dijalankan di komoditas kedelai hitam. Program itu memberikan peningkatan kapasitas pengetahuan dan keterampilan pada kelompok tani binaan agar bisa menciptakan dan memelihara varietas kedelai hitam unggulan.
}

Volume 1 (2) Desember 2016 eISSN 2528-1569 pISSN 2528-2115 (fertilizer). (4) Kebersihan dan kesehatan produksi gula (clean \& healthy). (5) Keselamatan kerja (safety prosedur). (6) Sekolah lapangan penderes (farmer field school) (YBU 2012).

YBU menugaskan dua LSM untuk menjalankan program ini, yakni Yayasan Citra Semesta (YCS) dan Yayasan Fasilitasi Inklusi (YFI). Masing-masing LSM memiliki penekanan program yang berbeda. Program YCS lebih banyak berupa penyaluran bantuan baik berupa dana, barang, perlengkapan, atau fasilitas lainnya. Semua itu bertujuan untuk membujuk para penderes. Sementara YFI bertugas meningkatkan kapasitas para penderes, terkait kesadarannya akan produksi gula kelapa yang berkualitas dan pemeliharaan tanaman kelapa sadapan.

Dalam menjalankan perannya, kedua LSM kerap menghadapi pertentangan antara idealisme mereka tentang pemberdayaan dengan kepentingan pragmatis pihak Ultrava. Misalnya dalam kasus YCS, pada tahap awal pelaksanaan program, YCS melakukan asesment terhadap para penderes dan menemukan masalah utama para penderes terkait dengan "persoalan harga gula kelapa yang tidak stabil; produksi gula yang menurun; penderes malas memupuk karena harga pupuk mahal, ditambah pohon kelapa bukan milik mereka; masalah resiko menderes yang berat; serta masalah kurangnya perhatian dari pihak-pihak terkait terhadap kesulitan hidup para penderes." Akan tetapi, meskipun sudah mendapatkan sudut pandang penderes, persoalan-persoalan di tingkat penderes kemudian hanya dibaca sebatas keterkaitannya dengan USAM. Program

\footnotetext{
${ }^{6}$ Wilayah Pangandaran dipilih karena jumlah pasokan gula kelapa yang mencapai $75 \%$ dari total kebutuhan untuk produksi Kecap Brasa. Selain itu, menurut penanggung jawab supply chain gula kelapa Ultrava, cita rasa gula kelapa Pangandaran yang khas turut membentuk cita rasa Kecap Brasa, sehingga tidak bisa dipisahkan dari bahan baku Bravo.
} 
pemberdayaan sudah dirancang dari pihak YBU dan tidak begitu mewakili kepentingan penderes.

Sementara itu dalam sekolah lapangan penderes, secara konsep sesungguhnya YFI memiliki tujuan untuk membuat penderes lebih kritis dalam melihat persoalan hidup mereka. Akan tetapi, dalam praktiknya sekolah lapangan berubah menjadi seperti pelatihan-pelatihan untuk menguasai keterampilan yang sesuai dengan standar USAM. Pelatihan-pelatihan itu berkisar dari manajemen organisasi, produksi pupuk organik padat dan cair, manajemen penggunaan pupuk kimia dan racun, pemeliharaan tanaman kelapa, penggunaan bahan kimia dalam racikan gula kelapa, pengelolaan dapur dan tungku yang bersih dan hemat, serta perihal prosedur keamanan memanjat dan keselamatan kerja.

Dalam situasi ini penderes binaan awalnya menolak penerapan USAM karena dianggap mempersulit kerja sementara tidak ada keuntungan lebih yang bisa mereka peroleh. Berbagai arahan tidak terlalu digubris penderes, karena tidak berdasar dengan permasalahan yang sudah mereka ajukan dalam asesment. Lama-kelamaan penderes mulai berani mengungkapkan pemikiran kritisnya melalui forum-forum pertemuan dengan pihak LSM pelaksana, PT Sentosa, Ultrava, dan Pemerintah.

Mengatasi penolakan penderes, YBU meminta YCS dan YFI menyesuaikan tiap agenda USAM dengan isu yang berkembang di tiap kelompok dan dikembangkan dari sudut aspek manfaat pada penderes. YCS mengaplikasikan strateginya dengan membuat program yang diusulkan sendiri oleh penderes. Strategi YCS yang lain adalah membuat penderes merasa bangga dengan diakui statusnya dan diberi perhatian oleh orang-orang penting. Hal itu cukup berhasil, meski program belum meningkatkan kesejahteraan penderes, adanya pengakuan berbagai pihak terhadap identitas para penderes selaku produsen komoditi unggulan bagi Pangandaran, bisa menjadi 'penawar.' Penderes yang terlibat program kemudian menerima disebut sebagai penderes binaan Ultrava, dan mereka diarahkan untuk menjadi agen yang menyebarkan gagasan-gagasan USAM pada penderes lainnya. Salah satu sarana melakukan itu adalah dengan merayakan Hari Penderes dan Temu Lapangan sebagai ajang sosialisasi kegiatan penderes binaan Ultrava ke publik.

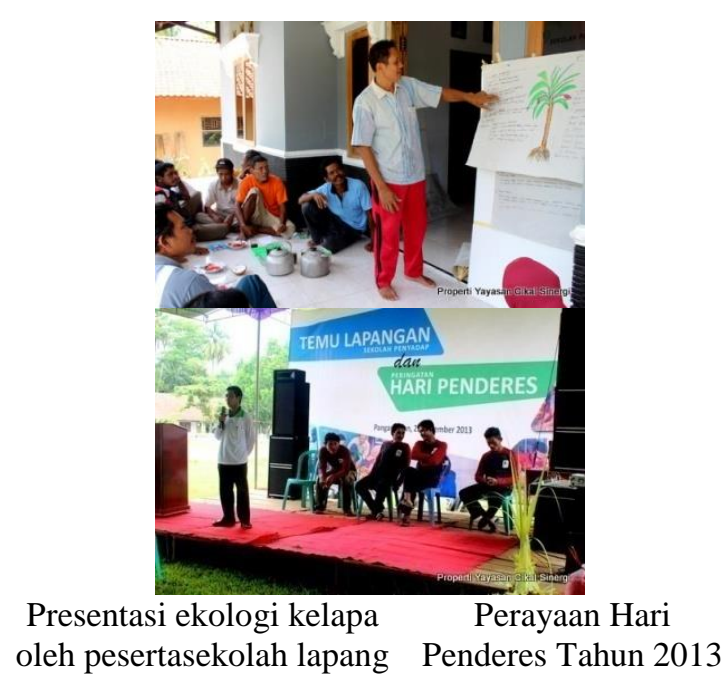

Dalam perspektif para pendukung CSR, apa yang dilakukan Ultrava dengan pemberdayaan penderes telah memenuhi indikator CSR terhadap pemasok. Seperti penjelasan Radyati (2008) bahwa pemberdayaan bisa mengurangi biaya manajerial atas pengelolaan rantai pasok dan memberi kesempatan untuk meningkatkan kapasitas pemasok. Program tersebut membantu Ultrava mengurangi biaya manajerial atas perlawanan penderes, terutama penolakan untuk kerjasama dan persoalan gula oplosan. Dengan melaksanakan program pemberdayaan, Ultrava memiliki kesempatan secara tidak langsung mendidik dan meningkatkan kapasitas para penderes dalam memproduksi gula kelapa yang sesuai standar Ultrava. 
Efek dari dari program seperti itu, sejalan dengan penjelasan Nursahid (2008), yakni pada akhirnya bermanfaat untuk meningkatkan kepercayaan dan loyalitas pemasok terhadap Ultrava. Sehingga juga memenuhi apa yang dikatakan Leimona \& Fauzi (2007), bahwa hubungan baik dengan pemasok dapat menjaga kelangsungan bahan baku, dalam hal ini lewat pemberdayaan penderes, Ultrava bisa mengatasi persoalan stabilitas dan kualitas pasokan gula kelapa Pangandaran untuk pabrik Kecap Bravo. Keberhasilan dalam manajemen pemasok, dengan kesediaan penderes menjaga sumber bahan baku sesuai dengan standar, pada akhirnya membuat program pemberdayaan Ultrava itu menambah peringkat sustainablity dan reputasi Ultrava di mata dunia bisnis.

\section{Penghalusan Dominasi Ekonomi Dalam Rantai Pasok Gula Kelapa Pangandaran}

Dalam Pengantar Antropologi Ekonomi (2002), Sairin dkk menjelaskan bagaimana para antropolog penganut ekonomi subtantif berupaya mengungkap nilai-nilai dasar yang tetap bertahan dari aktivitas ekonomi, baik di masyarakat tradisional maupun modern. Nilainilai itu melekat dalam sistem pertukaran yang berupa resiprositas dan redistribusi, yang dimanifestasikan dalam bentuk hadiah untuk menjadi pengikat dalam suatu kontrak sosial tertentu. Kerangka ekonomi subtantif itu juga bekerja dalam pelaksanaan CSR. Seperti yang ditemukan Dolan \& Rajak (2016), meski merupakan suatu aktivitas ekonomi di masyarakat modern, CSR pada dasarnya berpijak pada nilai resiprositas dan redistribusi yang bersifat tradisional.

Resiprositas merupakan pertukaran horizontal yang dilakukan antara orang-perorang dalam rangka saling tolong menolong memenuhi kebutuhan hidup. Dalam kerangka resiprositas, CSR menempatkan perusahaan sebagai warga negara dalam berhadapan dengan masyarakat dan stakeholder-nya.
Ultrava melaksanakan kegiatan CSR-nya sebagai warga Negara Indonesia, sebagai wujud kepatuhan terhadap nilai-nilai sosial yang berlaku umum, yakni saling membantu dan berbagi dengan sesama warga, dalam hal ini adalah para stakeholder-nya, termasuk para penderes di Pangandaran.

Sementara itu, redistribusi adalah pertukaran vertikal, yang bekerja dalam suatu organisasi sosial yang memiliki struktur patronase, bahwa ada kewajiban anggota mengumpulkan sumberdaya ke patron, lalu patron membagi kembali ke anggota melalui mekanisme tertentu. Dalam kerangka redistribusi, CSR menjadi mekanisme dari perusahaan untuk memberi reward pada stakeholder utamanya, yakni para pekerja, pemasok, dan konsumen yang telah menyuplai laba bagi perusahaan. Dalam skema ini dapat dibaca bagaimana CSR tersebut sebagai bentuk apresiasi atas kontribusi penderes pada Ultrava, dalam kata lain, tak ubahnya seperti politik etis yang dilakukan kolonial terhadap negeri jajahannya.

Seperti yang dijelaskan sebelumnya, dominasi Ultrava terhadap rantai pasok gula kelapa Pangandaran sangat kuat, dan menimbulkan eksploitasi berlapis dengan korban akhir adalah para penderes. Hal itu menimbulkan perlawanan dari penderes, yakni berupa gula oplosan dan penyelewengan pasokan yang mengganggu stabilitas pasokan untuk Kecap Bravo. CSR kemudian dilakukan sebagai penghalusan dominasi ekonomi untuk meredam kemarahan penderes sekaligus memperkuat pengaruh terhadap mereka. Pada akhirnya, baik dalam skema resiprositas maupun redistribusi, CSR merupakan gift dari Ultrava pada penderes, yang ujungnya mempertegas kontrak sosial antara Ultrava dan penderes. 
Fenomena penghalusan dominasi ekonomi atau euphemization of property relation ${ }^{7}$ mengikuti penjelasan James Scott (2000) atas upaya tuan tanah di Sedaka dalam mengatasi perlawanan sehari-hari kaum peasant. Menggunakan penjelasan dari Scott (2000:403-406), ada tiga konsekuensi eufemisme dominasi ekonomi yang juga muncul dalam pelaksanaan CSR Ultrava di Pangandaran, yakni;

1) Dominasi ekonomi harus dibayar dengan pemberian-pemberian yang memiliki nilai ekonomi kongkrit dan juga nilai-nilai simbolis seperti hadiah, pinjaman, sumbangan, dsb. Dalam aktivitas CSR Ultrava di Pangandaran, program pemberdayaan yang dilaksankan pada dasarnya memberikan berbagai macam bantuan pada penderes binaan, baik secara finansial, alat-alat hingga pendampingan. 2) Ongkos penghalusan dominasi ekonomi ini diambil dari hasil kerja, yang dikembalikan lagi (hanya sedikit saja) sebagai upaya socialization. Konsekuensi ini merupakan bentuk redistribusi (seperti yang dijelaskan di atas), yakni CSR Ultrava pada dasarnya apresiasi atas kerja keras para penderes, tentu saja dalam jumlah yang sangat sedikit dibanding laba yang didapat Ultrava dari keringat para penderes itu. 3) Penghalusan wajah hubungan ekonomi ini selalu menjadi pusat manipulasi, perjuangan dan konflik simbolik, berupa manipulasi simbol eufimisme secara resiprokasi (timbal balik). Golongan kaya memanfaatkan upaya tersebut agar citra dirinya menjadi baik di mata masyarakat. Sementara kelompok miskin memanfaatkan hal tersebut agar mereka mendapatkan kucuran bantuan dari orang kaya. Hal ini juga terlihat ketika Ultrava memanfaatkan kegiatan pemberdayaan sebagai upaya membangun citra yang baik terhadap penderes dan stakeholder lebih luas.

\footnotetext{
7 Istilah eufimisme ini berasal dari Pierre Bourdieu (1977 dalam Scott 2000:403), istilah ini memiliki makna bahwa eksploitasi secara lembut dan terselubung Volume 1 (2) Desember 2016 eISSN 2528-1569 pISSN 2528-2115
}

Sementara penderes juga memanfaatkan hadirnya program pemberdayaan untuk menuntut lebih banyak bantuan dan perhatian dari pihak Ultrava.

\section{Praktik Kepengaturan PT Ultrava Terhadap Rantai Pasok Gula Kelapa Pangandaran}

Sebagaimana yang dijelaskan oleh Li (2012), kepengaturan adalah "pengarahan perilaku", yakni upaya mengarahkan perilaku manusia dengan serangkaian cara yang telah dikalkulasi sedemikian rupa ( $\mathrm{Li}$ 2012:9). Terkait kepentingan kapitalisme, kepengaturan yang bertujuan untuk mengarahkan masyarakat pada jalan yang yang melanggengkan dominasi para penguasa kapitalis (Li 2012:41). Hal seperti inilah yang dapat kita lihat dari pelaksanaan program pemberdayaan penderes sebagai kepentingan Ultrava menerapkan USAM. Ada tiga strategi kepengaturan yang telah dilakukan Ultrava dalam pengelolaan rantai pasok gula kelapa di Pangandaran, yakni : 1) peran perwalian, 2) teknikalisasi permasalahan, serta 3) pendisiplinan.

Strategi Pertama, Ultrava menjalankan peran perwalian. Li (2012:41), menjelaskan bahwa peran perwalian muncul sebagai upaya memperbaiki dan menormalkan' orang-orang yang dinilai gagal dalam masyarakatnya. Upaya perbaikan itu diserahkan kepada pihak yang dinilai kompeten, yang memiliki pengetahuan tentang persoalan orang-orang gagal itu, dan memiliki serangkaian cara untuk memperbaikinya. Dari sudut pandang ini bisa dipahami bagaimana Ultrava yang diwakili oleh YBU, YCS, dan YFI memosisikan diri sebagai pihak yang berwenang untuk mengelola para penderes. Mereka mengambil posisi sebagai pihak yang merasa ahli tentang

adalah juga bentuk eksploitasi manusia atas manusia, jika eksploitasi kasar secara terang-terangan tidak mungkin dilaksanakan. 
persoalan penderes, dan memiliki solusi atas persoalan tersebut. Posisi itulah yang kemudian digunakan sebagai alat legitimasi untuk menjalankan pemberdayaan terhadap penderes.

Strategi kedua, untuk kebutuhan pengelolaan rantai pasok, YBU mengembangkan strategi asesment pemahaman konteks lokal. Asesment merupakan tahap yang disebut oleh Li sebagai teknikalisasi permasalahan, yakni upaya mencari serangkaian diagnosa, resep dan teknik untuk memperbaiki kekurangan yang ditemukan dalam problematisasi masalah. Sayangnya, asesment itu sudah disesuaikan berdasarkan apa yang menjadi persoalan dalam upaya penerapan USAM. Sementara itu, persoalan-persoalan yang ditemukan di lapangan terkait dengan tuntutan penderes tidak diakomodir. Gejala itu menunjukkan apa yang disebut Li sebagai hakikat dari praktik teknikalisasi masalah, yakni penegas kepakaran, melucuti aspek-aspek politis dan menegaskan status quo (Li 2012:13-17). Praktik teknikalisasi masalah itu telah melucuti aspek-aspek politis dari persoalan yang menyebabkan kesulitan hidup penderes, yakni hubungan eksploitatif dalam rantai pasok. Sebab itu, pada saat teknikalisasi masalah itu bersifat anti-politik, maka program pemberdayaan penderes itu sesungguhnya dilaksanakan untuk mempertahankan status quo Ultrava dan PT Sentosa.

Strategi ketiga, Ultrava menggunakan program pemberdayaan sebagai pendisiplinan terhadap rantai pasoknya. Lewat GPGK, YBU bisa mengorganisir penderes di Pangandaran dalam satu wadah, sehingga lebih mudah untuk diakses. Dengan akses tersebut, Ultrava mengenalkan tentang "aturan main" bagi penderes. Sebagai hasil dari berbagai teknik pendisiplinan itu, yang paling penting bagi Ultrava adalah peningkatan kapasitas penderes. Ketersediaan penderes dengan kapasitas sesuai USAM dibutuhkan oleh
Ultrava untuk menjaga keberlangsungan produksi gula kelapa yang berkualitas. Selain itu, kapasitas seperti itu juga dibutuhkan Ultrava untuk menuju pendisiplinan selanjutnya, yakni pada komunitas penderes yang lebih besar.

Jika kita melihat makna disiplin yang dibahas oleh Foucault (1977), maka kita akan menemui hakikatnya sebagai teknik pemantauan, pengawasan dan pengendalian diri yang dilakukan oleh individu pada dirinya sendiri. Bisa dikatakan, hal seperti inilah yang terjadi pada para penderes. USAM, sebagai rejim pengetahuan dari Ultrava, telah berhasil menjadi kebenaran bagi penderes. Padahal sebelumnya para penderes binaan ini tidak peduli, bahkan cenderung melawan berbagai standar produksi yang ditetapkan Ultrava. Namun setelah USAM itu ditransmisikan lewat program pemberdayaan, dan didukung dengan pengakuan terhadap status sosial sebagai binaan Ultrava, rejim pengetahuan tersebut akhirnya diterima oleh para penderes dan akhirnya menentukan tingkah laku pengaturan-diri sendiri yang penderes lakukan terkait aktivitas produksi gula kelapa.

Atas fenomena itu, kita bisa melihat apa yang dilakukan Ultrava dalam program pemberdayaan di Pangandaran dalam konteks yang disebut Foucault sebagai reproduksi manusia untuk reproduksi kapital. Kondisi ini sejalan dengan yang dikatakan Mulyanto (2012:188) dan Sherman (2015a), bahwa telah terjadi pendisiplinan tenaga-kerja manusia melalui pendidikan (dalam bentuk pemberdayaan), untuk menghasilkan tubuh yang patuh yang berguna dalam rangka pengelolaan subyek buruh di bawah sistem kapitalisme. Dalam situasi ini penderes telah didisiplinkan melalui pemberdayaan untuk menjadi rantai pasok yang patuh pada USAM. 
CSR Sebagai Strategi Hubungan Industrial Antara Perusahaan dan Mitra Pemasok Bahan Baku Produksi

Pemanfaatan pemberdayaan dan CSR dalam pengelolaan rantai pasok seperti yang dilakukan Ultrava ternyata bukanlah sesuatu yang unik dalam dunia industri. Dalam sektor industri hasil bumi, beberapa perusahaan lain juga melakukan kegiatan CSR seperti program Ultava. Misalnya Indofood yang mengembangkan program-program kemitraan pertanian secara berkelanjutan dengan para petani mitra yang terdiri dari petani kentang, singkong, gula kelapa, cabai dan kelapa sawit. Indofood memberikan pelatihan, bimbingan dan asistensi di bidang pembudidayaan, penanaman, pemanenan dan penanganan komoditas pasca panen (www.indofood.com). Kemudian PT Astra Agro Lestari juga melaksanakan kegiatan CSR di bidang ekonomi dengan meningkatkan kualitas hubungan kemitraan dalam berbagai bentuk PIR-BUN (Pola Perusahaan Inti Rakyat-Perkebunan) terhadap para petani kelapa sawit. Kegiatan CSR diarahkan untuk meningkatkan kapasitas petani sawit agar bisa menjadi mitra yang lebih baik bagi PT Astra (Astra Agro Lestari 2015). Hal serupa juga terjadi dalam penerapan IWAY (IKEA WAY) oleh IKEA Indonesia terhadap supplier dan para pengrajin rotan rumahan dalam rantai pasoknya, yang juga diklaim sebagai aktivitas CSR perusahaan tersebut. IWAY menjadi alat kontrol proses produksi perabotan rotan di tingkat pengrajin untuk memenuhi berbagai standar produksi terkait kepatuhan terhadap HAM, kesejahteraan pekerja, kelestarian sumber bahan baku, dan pengendalian dampak terhadap lingkungan (Lim 2015).

\footnotetext{
${ }^{8}$ Meski pandangan positif meyakini bahwa subcontract merupakan salah satu bentuk "trickle down effect" dan katalisator untuk pengembangan industry kecil menengah, namun Rustiani \& Maspiyati menguraikan bagaimana subcontract pada dasarnya adalah Volume 1 (2) Desember 2016 eISSN 2528-1569 pISSN 2528-2115
}

Fenomena ini mengungkapkan suatu perspektif berbeda tentang CSR. Jika sebagian besar kajian cenderung melihat CSR sebagai persoalan etika bisnis atau tanggung jawab mandatoris, maka dalam kasus pemanfaatan CSR untuk pengelolaan rantai pasok, CSR sudah menjadi inti dari kegiatan bisnis perusahaan yang berkaitan dengan hubungan industrial antara perusahaan dan pemasok bahan baku produksi. Hal ini mengingatkan pada sistem subcontract pada sektor industri hasil pertanian. Namun, berbeda dengan sistem subcontract yang cenderung menjadi lahan subur terjadinya eksploitasi dan menghasilkan konflik antara perusahaan dan pemasok $^{8}$, sebaliknya CSR lebih kepada strategi yang lebih canggih dan halus untuk mengatasi konflik sekaligus meningkatkan kualitas pasokan dan mempertahankan kemitraan antara pemasok dan perusahaan. Namun, meski lebih halus, pada dasarnya CSR memiliki tujuan yang tidak jauh berbeda dengan apa yang dilakukan perusahaan dalam sistem subcontract, yakni penghisapan terhadap rantai pasok. Dengan pendekatan yang lebih halus, CSR menjadi strategi penundukan terhadap rantai pasok yang menentang dominasi perusahaan. CSR telah menjadi penghalus dominasi ekonomi sekaligus alat kepengaturan dalam suatu hubungan industrial antara perusahaan dan mitranya.

Dalam hal ini CSR merupakan suatu sistem yang telah berhasil menjawab kekakuan hubungan industrial yang berlandaskan logika ekonomi formal. Sistem subcontract yang terlalu menekankan prinsip "kesepakatan bisnis" dengan minimnya kepedulian sosial terhadap mitra merupakan salah satu penyebab tingginya konflik dalam sistem tersebut. CSR dalam hal ini, merupakan

mekanisme perusahaan untuk mengalihkan resiko produksi atau resiko pemasaran. Hal inilah yang menjadi potensi terjadinya eksploitasi dan memicu konflik antara perusahaan dan mitra subkontraknya (Rustiani \& Maspiyati 1996). 
antitesis dari kondisi itu. CSR saat ini telah memanfaatkan kekuatan subtantif dari relasi ekonomi, yakni kenyataan bahwa aktivitas ekonomi tidak berdiri sendiri, namun dipengaruhi oleh kondisi relasi sosial antara aktor-aktor yang terlibat di dalamnya, sebaliknya relasi ekonomi juga memberi dampak terhadap relasi sosial para aktor yang terlibat di dalamnya. CSR menjadi salah satu aktivitas ekonomi modern yang menggunakan nilai-nilai tradisional, yakni dengan menjadikan sistem resiprositas dan redistribusi sebagai strategi untuk mengendalikan rantai pasok bahan baku industri.

Penutup : Pemberdayaan Sebagai Aktivitas CSR, Sebuah Tantangan Bagi Sarjana Antropologi

Paulo Freire pernah menegaskan bahwa pemberdayaan adalah "metode pendidikan dewasa non-formal yang didesain untuk membuat petani dan pekerja sadar mengenai dalam cara seperti apa mereka dieksploitasi oleh sistem feudal-kapitalis, dan bagaimana potensi mereka memberdayakan diri sendiri lewat aktivitas berkelompok (African Rights 1995:29 dalam James 1999:15)."

Kemudian menurut Singh \& Titi, sejatinya penerapan gagasan pemberdayaan digunakan untuk "...memungkinkan orang-orang memahami realitas dari lingkungan mereka (sosial, politik, ekonomi, ekologi dan kultural)... dan mengambil langkah perubahan untuk meningkatkan situasi tersebut. Pemberdayan melengkapi orangorang dengan kapasitas, ...untuk merasakan sebagai penguasa atas cara berfikir dan cara pandang mereka atas dunia, untuk mewujudkan harapan-harapan atas kehidupan yang baik (Singh \& Titi 1995:13-19 dalam James 1999:18-19)."

Akan tetapi, misi ideal dari pemberdayaan itu sepertinya jauh panggang dari api saat melihat pelaksanaan program pemberdayaan sebagai CSR terhadap pemasok yang dilakukan oleh beberapa perusahaan, terutama pada kasus Ultrava. Alih-alih memberikan pemberdayaan yang membebaskan para produsen dari eksploitasi dalam rantai pasok, tujuan pemberdayaan itu telah dibelokkan oleh kepentingan perusahaan, yang menggunakannya untuk menciptakan sumber daya manusia terdidik yang patuh.

Dari fenomena tersebut, sesungguhnya telah terjadi distorsi besar dari idealisme pemberdayaan saat dimanfaatkan perusahaan sebagai kegiatan CSR. Merupakan sebuah ironi, dari tujuan awalnya sebagai pembebasan dari jerat kapitalisme, pemberdayaan malah menjadi alat penjerat yang digunakan kapitalisme untuk menciptakan subjek buruh yang patuh. Kondisi itulah yang pada akhirnya menjadi "jebakan betmen" bagi para sarjana antropologi yang menjadi praktisi pemberdayaan yang masih berpijak pada idealisme pemberdayaan. Suatu kondisi yang membuat para sarjana antropologi terjebak dalam situasi yang dulu juga pernah dialami para pendahulunya, yakni menjadi bagian dari proses penjajahan.

Kondisi ini perlu dilihat sebagai tantangan bagi dunia pendidikan untuk meninjau kembali kuliah pemberdayaan masyarakat yang diajarkan pada mahasiswa. Dari distorsi yang terjadi, pembelajaran tentang prinsipprinsip ideal pemberdayaan ala Jim Ife (2008), atau teknik-teknik community development dari Philips \& Pittman (2015) rupanya belum cukup membekali para sarjana menghadapi dominasi kepentingan para kapitalis yang menjadikan program pemberdayaan dan CSR sebagai alat penghisapan. Sebab itu, kampus perlu memberi pembelajaran yang lebih kritis untuk membekali mahasiswa mempertahankan idealisme pemberdayaan saat bekerja dalam program CSR. 
Misalnya, selain membekali mahasiswa dengan berbagai prinsip dan teknik pemberdayaan yang menekankan proses perubahan di masyarakat, perkuliahan juga perlu memberi pembelajaran tentang logika ekonomi politik kapitalisme yang menjadi landasan kepentingan perusahaan terhadap pemberdayaan. Sehingga mahasiswa akan memperoleh pemahaman komprehensif terkait problem masyarakat dan kepentingan perusahaan. Kemudian mahasiswa bisa untuk mencari irisan di antara keduanya. Untuk menggunakan pemahaman itu dalam mengembangkan strategi yang merubah kondisi zero-sum akibat dominasi kepentingan perusahaan, menjadi kondisi win-win solution yang juga berpihak pada kepentingan masyarakat. Kelak hal inilah yang akan menjadi bekal utama untuk mempertahankan idealisme pemberdayaan.

Pada akhirnya, keterampilan memahami the others, kejelian menganalisa struktur dan relasi sosial, kemampuan menjadi interpreter dan negosiator antar pihak terlibat, serta ketepatan analisa dalam memberi rekomendasi akan menjadi seperangkat skill ekslusif yang dibutuhkan sarjana antropologi dalam menjalani perannya sebagai praktisi pemberdayaan. Namun semua itu harus tetap berpijak pada etika profesi antropolog, yakni keberpihakan dalam menjaga nilai-nilai kemanusiaan, keadilan dan keberagaman. Etika tersebut harus menjadi pegangan, dan menjadi sikap politik untuk menunjukkan bagaimana praksis antropologi sebagai ilmu yang meletakkan manusia pada derajat yang sebenarnya, dalam arti bukan sekadar alat bagi kapital. Sehingga para sarjana antropologi bisa turut berkontribusi dalam mengatasi distorsi pemberdayaan yang terjadi dalam praktik CSR.

\section{Daftar Pustaka}

AsiaDHRRA Secretariat.(1998). The Impact of Globalization on The Social-Cultural Lies of Grassroots People in Asia, Jakarta : Grasindo.

Astra Agro Lestari. 2015. Creating A Sustainable Future: 2014 Sustanable Report. Jakarta : Astra Agro Lestari.

Dolan, C. \& D. Rajak (edt). (2016). The Anthropology of Corporate Social Responsibility. New York : Berghan Books.

Foucault, Michel.(1977). Discipline and Punish : The Birth of The Prison, New York : Pantheon Books. .(1980). Power/Knowledge. New York: Pantheon Books.

Frynas, J.G.(2009). Beyond Corporate Social Responsibility : Oil Multinationals and Social Changes. New York : Cambridge University Press.

Ife, Jim \& Frank Tesoriero. 2008. Community Development: Alternatif Pengembangan Masyarakat Di Era Globalisasi. Yogyakarta : Pustaka Pelajar

James, Wendi. (1999). "Empowering Ambiguities." In Cheater, Angela. (edt). (1999). The Anthropology of Power : Empowerment and Disempowerment in Changing Structures. London and New York : Routledge.Pp. 13-27.

Leimona, B. dan Fauzi, A. (2008). CSR For Better Life: CSR dan Pelestarian Lingkungan, Mengelola Dampak: Positif dan Negatif. Jakarta : Indonesia Business Links.

Li, Tania Murray. (2012). The Will to Improve : Perencanaan, Kekuasaan dan Pembangunan di Indonesia. Jakarta : Marjin Kiri.

Lim, Lin Liam. 2015. Hubungan Kerja dan Kondisi Kerja di Sebuah Rantai Pasokan Rotan IKEA/Kantor Perburuhan Internasional Jakarta: ILO.

Mulyanto, Dede. (2012). Genealogi Kapitalisme : Antropologi dan Ekonomi Politik Pranata Eksploitasi Kapitalistik. Yogyakarta : Resistbooks.

Nursahid, Fajar. (2008). CSR Bidang Kesehatan dan Pendidikan : Mengembangkan Sumber Daya Manusia. Jakarta: Indonesia Bussines Links.

Philips, R (eds) \& Robert H. Pittman (eds). 2015. An Introduction to Community Development -2 Edition. New York : Routledge

Radyati, M \& Nindita, R. (2008). CSR Untuk Pemberdayaan Ekonomi Lokal, Jakarta: Indonesia Bussines Links.

Rustiani, F \& Maspiyati. (1996). Usaha Rakyat Dalam Pola Desentralisasi Produksi Subkontrak. Bandung : Akatiga. 
Sairin, S., P. Semedi \& B. Hudayana. (2002). Pengantar Antropologi Ekonomi. Yogyakarta : Pustaka Pelajar.

Scott, James. (2000). Senjatanya Orang-Orang Yang Kalah. Jakarta : Yayasan Obor Indonesia.

Sherman, Melina. (2015a). The "How" and "Why" Of Power: From Marx to Foucault to Power Today. http://melinasherman.com/2015/04/13/the-howand-why-of-power-from-marx-to-foucault-topower-today/. Diakses 12 Juni 2015. . (2015b). Foucault, Then And Now: On Modalities Of Power And The Making Of Subjects.http://melinasherman.com/2015/04/ 13/foucault-then-and-now-on-modalities-ofpower-and-the-making-of-subjects/. Diakses 12 Juni 2015.

Sukada, Sony dkk. (2007). CSR for Better Life : Indonesian Context : Membumikan Bisnis Berkelanjutan Memahami Konsep \& Praktik Tanggung Jawab Sosial Perusahaan. Jakarta : Indonesia Business Links (IBL).

Sum, Ngai-Ling. (2009). Articulation of 'New Constitutionalism' with 'New Ethicalism': WalMartization and CSR-ization in Developing Countries. In Peter Utting (ed.). (2009).

Corporate Social Responsibility and Regulatory Governance: Towards Inclusive Development? London: Palgrave.

Vertigans, Stephen. (2011). CSR as Corporate Social Responsibility Or Colonial Structures Return? A Nigerian Case Study. International Journal of Sociology and Anthropology. Vol. 3(6) pp. 159-162, June 2011. Available online http://www.academicjournals.org/ijsa.

Widyaningrum, N., R. Dewayanti, E. Chotim, I. Sadoko. (2003). Pola-Pola Eksploitasi Terhadap Usaha Kecil, Bandung : Yayasan Akatiga. 